
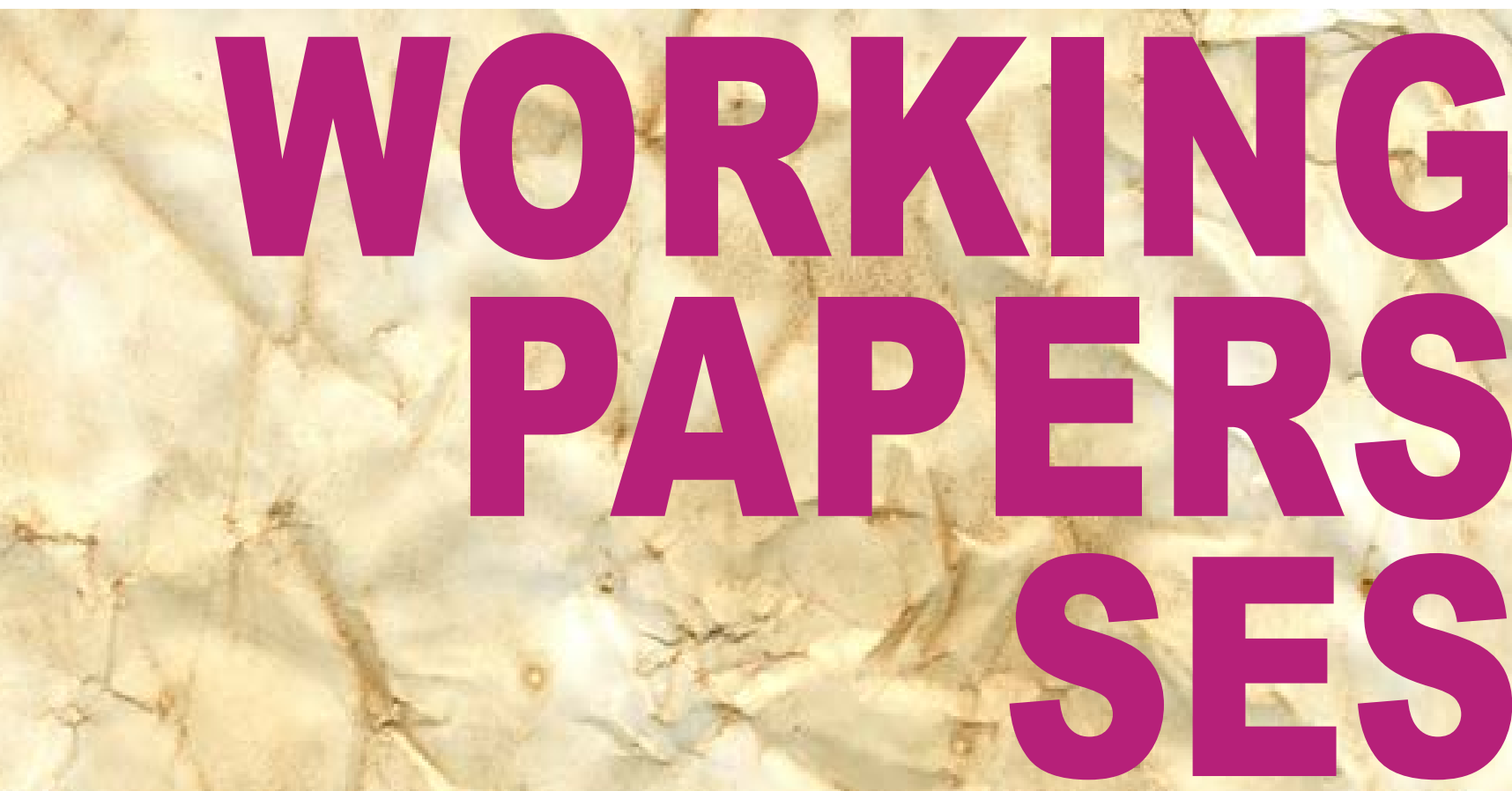

A Framework for Innovative Service Design

Olivier Furrer, Devanathan Sudharshan, Rodoula H. Tsiotsou, and Ben S. Liu 


\title{
A Framework for Innovative Service Design
}

Olivier Furrer (corresponding author)

Department of Business Administration, University of Fribourg, Bd de Pérolles 90, 1700

Fribourg, Switzerland, phone: +41 26300 8306, email: olivier.furrer@unifr.ch

D. Sudharshan, Gatton College of Business and Economics, University of Kentucky, 255

Gatton College Building, Lexington KY 40506, USA, phone: +1 859257 8939, email:

devanathan.sudharshan@uky.edu

Rodoula H. Tsiotsou, Department of Business Administration, University of Macedonia, 156 Egnatia Str., Thessaloniki 54636, Greece , phone: +3 23108 9157, email: rtsiotsou@gmail.com

Ben S. Liu, Department of Marketing, Lender School of Business Center, Quinnipiac University, 275 Mt. Carmel Avenue, Hamden, CT 06518, USA, phone: +1 203582 3772, email: ben.liu@quinnipiac.edu

\begin{abstract}
Drawing on research from design science, marketing and service science, our paper provides an integrated framework for evaluating and directing innovative service design. The main goal of our review is to highlight the strengths of existing frameworks and to suggest how they can be enhanced in combination with design science principles. Based on our review, we propose a new framework for the design of innovative services that integrates several key paradigmatic approaches and identifies fundamental open research questions. Our approach is unique as it combines three service disciplines, namely services marketing, service science, and design science, and provides a new framework that describes step by step the procedure that needs to be taken and the conditions that need to be met for developing innovative services. We believe that providing such a framework is a valuable addition to the literature.
\end{abstract}

Keywords: Service design, Services innovation, Marketing science, Design science, Servicedominant logic, Customer co-creation, Customer co-production 


\section{Introduction}

As services play an increasing role in economies around the world, the study of what has been termed “service science” has become ever more important for enterprises (Maglio \& Spohrer, 2008; Spohrer \& Maglio, 2008; Vargo \& Akaka, 2009). Simon’s (1956, p. 132) framework for the "science of design" calls for a body of intellectually tough, analytic, partly formalized, partly empirical teachable doctrine. As service science develops, there is a need for a formal scientific framework for the development of innovative services (Gadrey \& Gallouj, 2002; Kelly \& Storey, 2000 ; Thomke, 2003; Frei, 2006; Ostrom et al., 2010). This need is further supported by Hauser et al. (2006, p. 706), who note that "Building platforms that link engineering and marketing decision making and constraints into integrated systems” remains a research challenge.

Moreover, recent literature on service design and marketing (Kimbell, 2011; Patrício \& Fisk, 2013) has argued that service design should be viewed as a holistic, multidisciplinary field that helps to innovate services so they offer value to the customer, and are effective, efficient, and distinctive to the service provider. As service design requires the integration of multiple areas of expertise, such as service science, management, engineering and the social sciences, all integrated through the use of design based principles; there is a need for an integrative design framework for the design of innovative services (Kelly \& Storey, 2000; Menor, Tatikonda, \& Sampson, 2002).

The goal of this paper is to develop such an integrative framework based on the building blocks from marketing, service, and design sciences. To do so, first, we relied on existing reviews and a search of the extant literature to cover the knowledge base as best as we could to conduct a review of the relevant literatures in these different fields. The main goal of our review is to highlight the strengths of existing frameworks and to suggest how they can be enhanced in combination with design science principles. Then, based on our review, we propose a new 
framework for the design of innovative services that integrates key paradigmatic approaches and signals directions for future research. Our approach is unique because it combines three servicerelated disciplines, namely services marketing, service science, and design science, and provides a new framework for developing innovative services while it describes step by step the procedure that needs to be taken and the conditions need to be met.

\section{Marketing Approaches to Services}

According to recent review articles (Carlborg, Kindström, \& Kowalkowski, 2014; Droege, Hildebrand, \& Heras Forcada, 2009; Ryu \& Lee, 2016), the study of services and service innovation is taking several forms. On the corporate side, IBM has been the prime mover in the development of Service Science, Management and Engineering (or SSME) much like the role it played in the development of Computer Science in the 1960s (IBM, s.d.). According to Jim Spohrer, Director of IBM Almaden Service Research Center, there are two key reasons for this development at IBM: '(1) we are realizing that the service economy and the knowledge economy are two sides of the same coin, that we should now term the innovation economy; (2) we also believe that significant productivity gains due to services are likely to occur soon at regular time periods, much like Moore’s law for semiconductors (Moore, 1965).’ Today, IBM’s SSME ideas have attracted the attention of close to one hundred and fifty universities that are developing activities around the themes in collaboration with IBM.

On the academic side, several approaches to the development of service marketing may be noted. For example, there has been the French School of service marketing research with its servuction model (e.g., Eiglier \& Langeard, 1976; Langeard \& Eiglier, 1987) and the North American School with the servicescape model (Bitner, 1992). More recently, however, Steve Vargo and Bob Lusch (2004) have taken the lead in calling for businesses and marketing 
academics to adopt a S-D ecosystem view (Vargo \& Lusch, 2011) while the Nordic School has proposed a Service Logic (SL) in an effort to reinvent marketing from a service perspective (Grönroos \& Gummerus, 2014), and finally, the Center for Services Leadership at Arizona State University (Ostrom et al., 2010) has called for the development of a 'Service Science approach.'

\section{Vargo and Lusch's Service-Dominant Logic}

According to Vargo and Lusch's (2004) S-D logic framework, a service is (1) the application of competences (e.g., knowledge and skills) by one party for the benefit of another and is the underlying basis of exchange, (2) the service system is the proper unit of analysis which is a configuration of resources such as people, information and technology, (3) service science is the study of service systems and of the co-creation of value (Vargo, Maglio, \& Akaka, 2008; Tari Kasnakoglu, 2016), (4) customers should always be considered as value co-creators, and (5) value is contextually determined by customer’s used situation (Vargo \& Lusch, 2011; Edvardsson et al., 2011; McColl-Kennedy, Cheung, \& Ferrier, 2015). Thus, the role of service providers is not limited to offering value propositions but to collaborate with customers and other actors to develop mutually beneficial value propositions (Vargo, 2009).

Similarly, the Service Logic (SL) views value as customer driven and created in customer processes (Grönroos \& Gummerus, 2014). The SL supports that service providers have an opportunity to engage with their customers and co-create value with them. As a result, the service provider is not restricted to offering value propositions, but only in some cases, also can directly and actively influence customers’ value fulfillment (Grönroos \& Gummerus, 2014). The value generation process takes place in three value spheres: 'a provider sphere that is closed to customers, where the service provider compiles resources, including potential value-in-use, to be offered to customers to facilitate their value creation; a joint sphere in which the service provider 
and customers interact directly, which enables the provider to engage with customers' value creation and co-create value with them; and a customer sphere, which is closed to the service provider and where the customers independently create value and may socially co-create value with actors in their ecosystem’ (Grönroos \& Gummerus, 2014, p. 208-209).

The implication of the S-D logic and the SL for service innovation and design is that customers must be involved at various stages of the service development process, and those customers' use situations and value co-creation activities and interactions are critical (Edwardson et al., 2012). This perspective is aligned with the recent swift of attention in the design field on participatory design processes, especially co-design which involves stakeholder participation throughout the design process (Steen, Manschot \& De Koning, 2011; Saunders \& Stappers, 2008).

\section{Service Science}

The service science approach called for by Ostrom et al. (2010) identifies the leveraging of technology as a key element to advance service. For example, according to Ostrom et al. (2010), it is the changes in computational and communications technology and the talent that enables them to serve users that are really the raison d'être for the new logic of marketing as well as the SSME initiatives. The design of new value providing entities within this new view has to give special consideration to the capabilities of the inherent technologies, and that of the talent that together become part of the entity that provides value to individual users or a group of users. The ability to interact with, adapt to the circumstances of, customize for and co-produce with users and in many instances to be able to measure and demonstrate the value generated for users (e.g., displaying savings by using electricity at optimal times, calories avoided by substituting foods, 
enhanced survival rate due to early intervention, etc.), and provide a human touch become salient for the development of the best design science and practice.

But, what is a scientific framework for evaluating a service design? And perhaps more importantly, what is a scientific framework for judging whether a service design is innovative and a good design? Having such a framework need to provide not only ex post evaluative abilities but also provide guidance for ex ante and in situ (thus allowing for co-creation) service design.

\section{The Principles of Design Science}

There are three core dominant approaches to a science of design and innovations (Suh, 2005, Vaishnavi \& Kuechler, 2015) ${ }^{1}$. The first follows the work of Suh (1990) and his axiomatic design principles. The second follows the TRIZ (Teoriya Resheniya Izobretatelskikh Zadatch) methodology (also referred to as the Theory of Inventive Problem Solving or TIPS by Sushkov, Mars, \& Wognum, 1995) developed by Altshuller and his colleagues (starting in 1946, Altshuller, 1986, 1988, 1996). The third is an approach developed at the University of Bath in the U.K. to bring the work of Suh and Altshuller together to develop an even better design science algorithm and tool set for inventors and designers (Mann, 1999a, b). Together these approaches represent a sea change in our understanding of what distinguishes true innovations from incremental changes. They provide necessary criteria by which new designs may be judged for their ability to solve customer problems in new ways.

\section{Suh's Axioms and Approach}

Nam P. Suh (at that time a Professor at M.I.T.) brought science to the art of design and his 1990 and 2001 books are paradigm setters (Suh, 1990, 2001, 2005). These books arose out of a need perceived by the United States National Science Foundation to develop a science of design as foreseen by Simon (1956). Gonçalves-Coelho and Mourao (2007) describe Axiomatic design 
(AD) as 'an engineering design theory that provides a framework to decision-making in the designing process' (p. 81). Their paper provides an example of a detailed application of AD to the design of a product. In his books, Suh describes the process of design (see Figure 1) as starting with identifying society's or user's needs, specifying the corresponding functional requirements, creating the design parameters, identifying the process variables, and constraints. Next, and the specific part where his overall process differs from that of marketing science, the Suh process links the functional requirements and the design parameters through a design matrix following his axioms. Then, a process of ideation and creation follows. The outcome is compared to the requirements and his axioms, and iterations through the process carried out till a satisfactory solution is obtained.

Figure 1: Depiction of Suh's Axiomatic Design Process

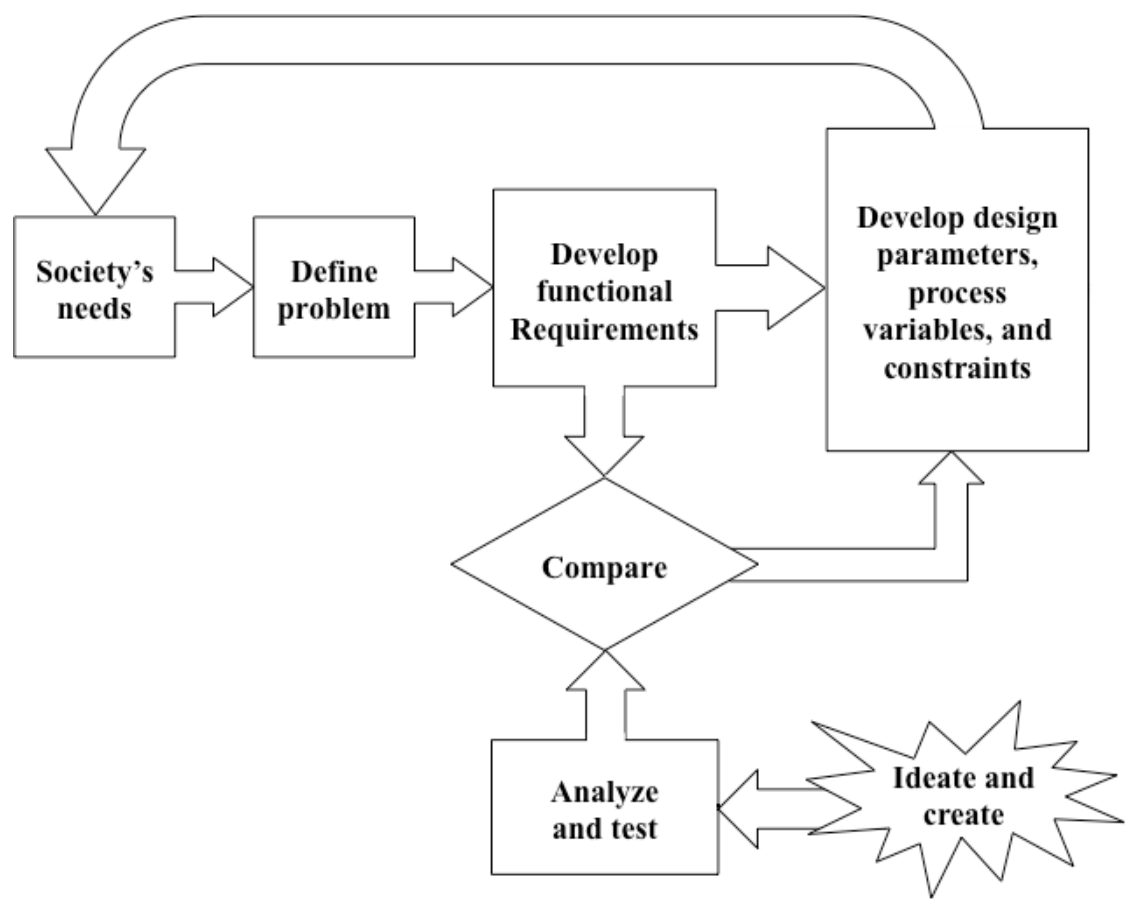

The scientific contribution of Suh's work is in its specifications of axioms that act as touchstones to the design process (Gonçalves-Coelho \& Mourao, 2007). The two axioms that govern the process of arriving at/evaluating the best solution are: 
A. The independence axiom states that the independence of corresponding elements from domain-to-domain should be maximized.

B. The information axiom states that the information content of a design should be minimized.

The independence axiom ensures that each functional requirement is delivered by one and only one design parameter. This axiom is intended to minimize unintended consequences and to make the end result easier to control (Brown, 2006). If the same design parameter is necessary to affect changes in both the functional requirements, by definition it will not be possible to change one of the requirements without affecting the other. For example, in designing a fast-food service two functional requirements needed may be (1) accuracy of order taking and (2) speed of preparation. Consider a design where a single individual both takes the order and prepares the food. If increasing the order accuracy requires the server to repeat the full order, obtain confirmation, and then proceed to fill the order, then increasing order accuracy increases service time. However, if order taking was performed by a separate order taker (perhaps a machine), confirmed one item at a time and relayed one item at a time to the preparer both accuracy and speed could be improved and tweaked independently. The independence axiom also minimizes the chances of unintentionally affecting other outcomes.

The information axiom provides the basis for choosing between alternative designs that each satisfies the independence axiom for a set of user needs. Its goal is to maximize the chance that a solution design will have the maximum chance to succeed. So, for example, a voice recognition system with the ability to span a variety of accents will be superior to one with the ability to a narrower range of accents. In general, a solution candidate may be such that it may deliver a set of outcomes within which a subset may be the desired outcome. The superior solution will be the one for which the number of possible outcomes to the outcome desired is a minimum. To 
continue with the same example, if a voice recognition system outputs several alternatives based on a single voice input (the desired output is one: the meaning of the voice input provided for the purpose of delivering the needed food item) it will be inferior to one producing one unambiguous and correct output. More generally, as stated by Brown (2006, p. 9), 'the design needs to be such that the tolerances can be broad and the functions still achieved.'

While the 'goodness' of a design is specified by the Suh axioms we find a definition for what constitutes an innovation in the work of Altshuller that is next discussed.

\section{The TRIZ Approach}

TRIZ is a systematic problem-solving methodology based on the assumption that there are universal principles of invention that are the basis for creative innovation (Chai, Zhang, \& Tan, 2005). The development of the TRIZ approach started when Altshuller worked in the Soviet Navy as a bureaucrat involved in the initiation and verification of research proposals and patent applications. He noticed that most patents involved inventions that allowed two conditions to be met that were previously viewed to be contradictory to each other. In other words, inventions cut the Gordian knots of trade-offs. Inventions decoupled two or more parameters that were so coupled together so that if one changed in a favorable direction, the other will necessarily change in a less favorable direction. He then set about studying patents to discern patterns to the resolution of contradictions or trade-offs and these patterns became central to the TRIZ approach to innovation and design (see Figure 2 next page). 
Figure 2: A Representation of the TRIZ approach

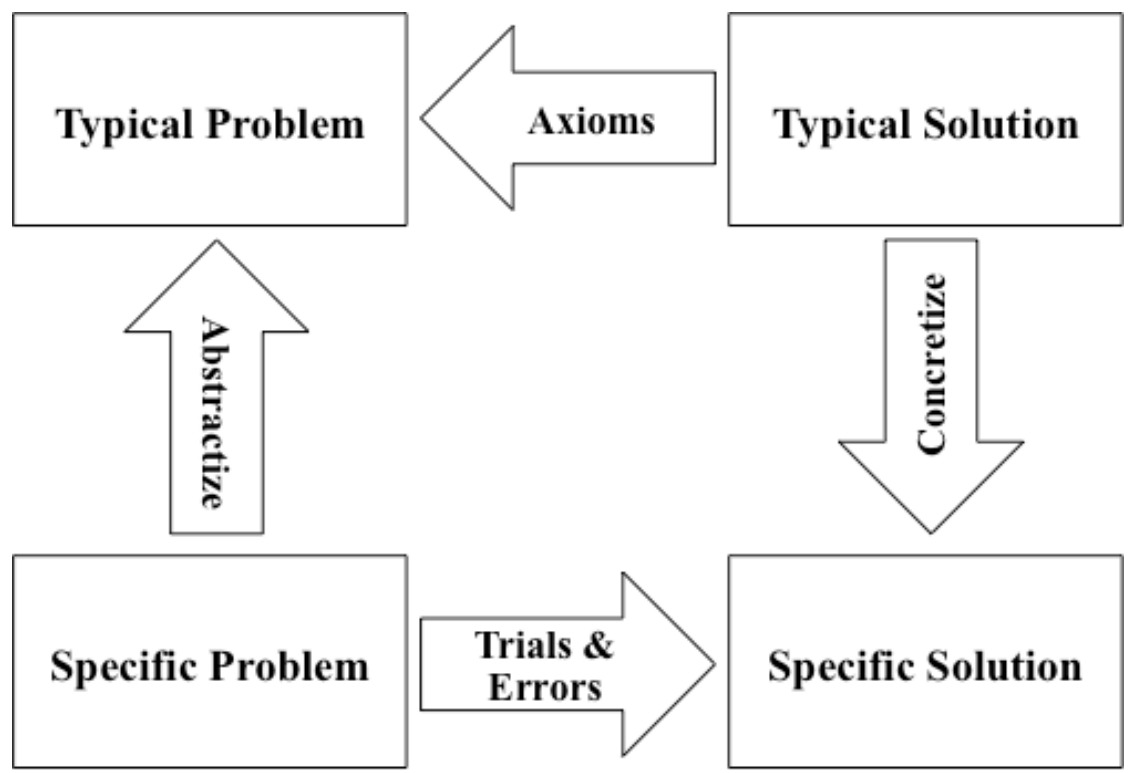

The three axioms that form the TRIZ approach (adapted from Slocum, 2014) are:

A. The technical contradiction axiom: the resolution of a problem is based on the identification and selection of contradictory technical requirements of system.

B. The physical contradiction axiom: the resolution of a problem is based on resolving contradictory physical parameters of a system element.

C. The ideal final result (IFR) axiom: the ultimate resolution to a problem (technical, physical or otherwise) is one that provides full useful functionality with no associated harm or cost.

While the $\mathrm{AD}$ approach provides principles for optimizing a design solution, the question of what constitutes an invention and thereby circumscribing the solution possibility space is answered by the TRIZ approach. Moreover, Chai, Zhang and Tan (2005), Zhang, Chai and Tan (2003), and Dourson (2004) provide specific applications of TRIZ principles to services. 


\section{Bringing together Suh's AD Approach and Altshuller's TRIZ Approach}

A group of scholars at the University of Bath in the U.K. took the lead in integrating the two approaches. Mann (1999a) notes that the two approaches are complementary and both he and Slocum (2014) suggest that a synthesized approach be developed for developing inventions. In particular, the TRIZ approach provides discipline to the 'Ideate and Create' phase of the AD approach. The $\mathrm{AD}$ approach, on the other hand, provides discipline to the problem identification and solution development processes in TRIZ by explicitly focusing on the hierarchical nature of the relationships between needs, functional requirements (contradictions), and design parameters.

A test of the sufficiency conditions of Altshuller is provided by Maimon and Horowitz (1999). They set out to answer the question as to when a design invention is a creative design invention. They identified the prevailing theory as the TRIZ approach, tested it, identified inadequacies in it, and then theorized a set of sufficiency conditions that they again put to test (by testing their ideas with a pool of domain experts) before claiming that if these conditions were met by a design invention then that design will indeed be a creative one. Their testing and analysis of TRIZ revealed two shortcomings: it was not sufficiently well defined and the solutions were not necessarily creative. Complementing TRIZ with AD alleviates the first shortcoming. In fact, Maimon and Horowitz did indeed resort to the AD approach to alleviate the first shortcoming of TRIZ. Maimon and Horowitz called their new condition, which is based on Suh's Independence Axiom, the Qualitative Change (QC) condition. To ensure that the solution was creative they developed a second condition called the Closed World (CW) condition that restricts the type of modifications that are permissible for a design to be called creative. They claim and show that their conditions together provide sufficient conditions for a creative design. Their process is another way to synthesize AD and TRIZ as advocated by Mann and his colleagues at Bath and Slocum at the Inventioneering Company. 
Thus the two approaches, TRIZ and AD, cover the range from ideation to solution development needed for a complete disciplinary approach to achieving a design solution to customer needs.

\section{The Axioms of Design Science}

In summary, the three axioms of Design Science may be written as:

A. The independence axiom states that the independence of corresponding elements from domain-to-domain should be maximized.

B. The information axiom states that the information content of a design should be minimized.

C. The invention or breakthrough axiom: the resolution of a problem is based on resolving contradictory parameters of a system element.

Please note that we have left out two of the TRIZ axioms. The first axiom that we have left out (IFR) is the do no harm axiom that we assume to be a given (for marketing/service applications). The second axiom that we have left out is the technical contradiction axiom that is already built into the invention or breakthrough axiom.

Marketing Science has developed a strong body of knowledge and practice on customers and competition for their attention and dollars (Kotler et al., 2015). Further, the determination of user needs and the management of the process of informing, persuading and creating user satisfaction and loyalty and pricing to ensure value appropriation from users fall under the purview of marketing science (Hauser et al., 2004). Once customer needs have been identified and their intensity and size evaluated as being sufficiently important to represent an attractive opportunity, marketing science assumes that products and/or services can be 'easily' designed to satisfy customers. What design science brings to marketing science are the axioms that need to be met 
by a design solution to a customer need. We now turn our attention to a brief look at how marketing science identifies user needs.

\section{Marketing Science: Identifying User Needs}

Marketing is informed by a taxonomy of needs (functional, social, emotional, epistemic, and conditional) based on the values being sought (Sheth, Newman, \& Gross, 1991) and a taxonomy based on type of buy (rebuy, modified rebuy, and new buy, etc.) (Kotler et al., 2015). Typically, qualitative marketing research, such as focus groups, interviews, and observational research, is used to identify user needs that are not being served or not being served adequately enough and quantitative marketing research methods are then used to measure the intensity of these needs as well as to measure the size of such opportunities (Hauser et al., 2004).

In the 1980s and 1990s, as the awareness of the inefficiencies in new product development, measured in terms of success rates from concept to profitability and development cycle time, grew in the marketing science community, considerable effort began to be invested on research into improving the new product development process itself (e.g., Veryzer, 1998). The objective became to launch new products that served user needs with the right quality at the right time.

To develop new products that meet customer needs, it was realized, that customer needs had to be measured more systemically. Three sets of techniques, in particular, that have had significant impact that emerged are Lead User Analysis (Herstatt \& Von Hippel, 1992; Urban \& Von Hippel, 1988; Von Hippel, 1986), Voice of the Customer (Griffin \& Hauser, 1993; Katz, 2001; McQuarrie, 1998), and Conjoint Analysis (Green \& Srinivasan, 1978, 1990). These techniques were powerful in identifying attributes needed by customers. On the other hand, they did not particularly incorporate the intangible/process elements that are essential to the design of services (Droege et al., 2009; Nijssen, Hillebrand, Vermeulen, \& Kemp, 2006). 


\section{Lead User Analysis}

Lead User Analysis (LUA) grew out of the work of Von Hippel $(1976,1977)$ in understanding the role of users in innovations. The fundamental breakthrough in this stream of literature is the insight that in many contexts there exist users whose needs exceed the capabilities of current products in a market and thus have already innovated solutions to address their specific needs. LUA is then a process by which such users may be identified and their knowledge of needs and solutions may be used to develop products for general population customers.

Urban and Von Hippel (1986) provide empirical evidence that firms that used LUA, had on average approximately eight times the return on their new products relative to firms that did not. Recent empirical studies also found that the use of LUA can help reducing the risk of failure while increasing effectiveness of new product development (Lüthje \& Herstatt, 2004), can increase the rate of success of new product introductions (Lilien et al., 2002), and can increase the speed of implementation of major new products (Mammone, 2010; Schreier \& Prügl, 2008).

LUA can be an effective method for identifying new trends and developing products, but it is not without its drawbacks. LUA is based on the assumption that the perceptions of lead users are representative of the larger population, the non-lead users (Von Hippel, 1977). However, it is possible that the products that the lead users desire will not be popular with the non-lead users. For example, Urban and Von Hippel (1988) show that in some cases, it may simply take time for the non-lead users to 'evolve' their needs and preferences to catch up with the lead users, but it also may be possible that certain concepts will only ever appeal to the lead users.

Lead users involvement in new service design brings in 'expert' users and others into the design regimen and thus helps in building in their view of needs and solutions. However, LUA does not lead to an invention or a new product that meets with design axioms. 


\section{Voice of the Customer}

Griffin and Hauser (1993) introduced the 'Voice of the Customer' (VOC) as a methodology involving both qualitative and quantitative marketing research for developing a set of user needs, clustering them into attributes and then attaching importance weights to them. These attributes and their corresponding weights then govern the design process. They investigated U.S. and Japanese firms that used the Quality Function Deployment (QFD) process for new product development, which is a quality management process where the VOC is implemented. The VOC aspect of QFD is that it identifies the customer's needs, structures the needs, and assigns priorities to customer needs (Griffin \& Hauser, 1993).

Several studies applied VOC and QFD in service contexts to develop new services. Burgers et al. (2000) applied the concept to service encounter in call centers to determine what customer expectations were in regard to employee behavior during voice-to-voice encounters. Teehan and Tucker (2010) discussed how VOC can be used to improve service delivery in call centers and show that using VOC to understand service failure and to evaluate customers' response to these failures helped to improve services provided by call centers. However, given the inherent difficulties to apply VOC and QFD in an intangible and co-creating service context (Dubé et al., 1999; Tan \& Pawitra, 2001), Li et al. (2009) have proposed a new service quality function development (SQFD) based on the gap analysis.

Like LUA, VOC has been very useful in highlighting customer perceptions of existing products and their attributes as well as in identifying some opportunities for new products (Hauser et al., 2006). While the VOC analysis helps identify need attributes, it does not identify the tradeoffs that should be broken. In other words, it does not shine light on the attribute tradeoffs that need to be subject to a breakthrough design efforts (Chai et al., 2005). By 
incorporating TRIZ principles, and in particular the Breakthrough axiom, design processes can be transformed and result in inventions and thus higher competitiveness (Kim \& Yoon, 2012).

\section{Conjoint Analysis}

The conjoint analysis methodology provides a theory of measurement for calibrating user importance weights for the various features/attributes of a product and for measuring the trade-off values users attach to giving up one level of a feature versus another. Green and Srinivasan (1978, 1990) provide literature reviews of the development and use of conjoint analysis.

Customer measurements are based on obtaining their preferences and perceptions for a set of stimuli that are presented to them using an appropriate experimental design. These measurements are then used to develop optimal new product positions (Sudharshan, May, \& Shocker, 1987; Sudharshan, May, \& Gruca, 1987; Green, Carroll, \& Goldberg, 1990; Sudharshan \& May 1991; Gruca, Sudharshan, \& Kumar, 1995). Significant advancements in measurement and estimation (calibration) of trade-offs and the generation of new products have subsequently been reported for example by Toubia et al. (2003), Urban and Hauser (2004) and Camm et al. (2006).

Conjoint Analysis takes as given that tradeoffs exist between attributes. It measures the tradeoffs and uses this measurement in attempting to optimize the new product to be developed. However, by its very canonical assumption of attribute tradeoffs, it rules out invention. In adding to measuring tradeoff values if customer response to breakthroughs were to be measured an augmented conjoint analysis might lead to inventive and competitively superior solutions that satisfy customer needs.

\section{Designing Services}

To overcome the deficiencies of these methods initially developed for tangible product contexts, service scholars have developed tools specifically designed for service innovations (Fisk et al., 
1993). Service design capacity is a key asset for innovation, as design thinking approaches help embed service logic into innovation processes. In particular, they add context (SEVQUAL, Experience Prototyping) and a focus on process mapping (Blueprinting).

At a most general level of exposition, several frameworks have been developed by service scholars to help the design and development of new services (Lin \& Cheng, 2015). Among them, a few have been extensively used in practice and studied: Blueprinting (Shostack, 1977, 1984, 2001), SERVQUAL (Parasuraman et al., 1988, 1991), Experience Prototyping (Buchenau, 2000; Thomke, 2003), and co-creation and service innovation (Hilton \& Hughes, 2008).

\section{Blueprinting}

During her tenure as a Vice President at Citibank, Shostack $(1977,1984,2001)$ pioneered blueprinting as a methodology for designing services. The intent was to visually show the entire delivery system and the flows between its various components. The impact of this development was such that it became a part of the British Standard for Service Design (BS 7000 -3, BS 7000 10, BS EN ISO 9000). This standard for services, following Shostack, describes blueprinting as the mapping out of a service journey identifying the processes that constitute the service, isolating possible fail points and establishing the time frame for the journey. The work of Bitner (1992) on ‘servicescapes' also fits into this category. It provides a typology of service organizations as well as a discussion understanding the impact of physical surroundings on customer and employee behavior. Bitner's study highlights the need to and ways to incorporate physical surroundings in the design of services. It therefore adds an important functional requirement or a set of functional requirements to be considered in the design matrix for the implementation of an integrated design regime. 
The service process is complex, and a blueprint provides a depiction of a process flow. A criticism of Blueprinting is that basic blueprint models fail to fully account for the differences in customer activity, for example whether they are active or passive in the process, and the number of customer touch points during the process (e.g., Szende \& Dalton, 2015). While these criticisms may be taken care of by advanced Blueprinting, two major gaps remain. The two gaps correspond to two design axioms. The first gap can be redressed by explicating Blueprints that identify and position independent function delivering subsystems. The second gap can be addressed by ensuring completeness and robustness in design. As mentioned earlier, these will be required as an essential part of Blueprinting if design axioms are part of service science.

\section{SERVQUAL}

The second theme of customer service satisfaction measurement is best represented by Parasuraman, Zeithaml and Berry (1988) and Parasuraman, Berry and Zeithaml (1991). They developed, through a rigorous process of construct development and testing, a service satisfaction measurement instrument called SERVQUAL. The key factors of SERVQUAL are reliability, assurance, tangibles, empathy and responsiveness. These need to be part of the testing conditions for any new design.

\section{Experience Prototyping}

The third theme is represented by Buchenau and Suri (2000) and Thomke (2003). Buchenau and Suri (2000) propose the use of ‘Experience Prototyping’ as a form of prototyping that involves all parties having a stake in the design and delivery of a service. Thomke (2003) discusses the traditional view of why formal R\&D processes do not exist for services as it may not be possible to build a small scale model that can then scale up because of economic or simply production infeasibilities or even the non-replicability of situations that a user will face at the time of 
necessity. He then describes a case example of the use of a scientific and rigorous process at work in Bank of America for the design of new services.

\section{Co-Creation and Service Innovation}

In keeping with the S-D logic (Vargo \& Lusch, 2004), a fourth theme considers that customers are important co-creators of value during the service consumption process. In light of the changing roles of customers from service co-producer to value co-creator, the customer participation literature has conceptualized two types of participation behavior: value co-creation and co-production (Lusch \& Vargo, 2008). Hilton and Hughes (2008) examine both co-creation and co-production by looking at the result of co-production in the application of self-service technology. Understanding the concept of co-production which emphasizes the need to understand productivity from the point of view of the customer, and demonstrate how this can be applied in both the consumer and inter-organizational contexts. Service organizations could benefit from identifying co-production with task performance and co-creation with the 'valuecontributing aspects’ of the customer service experience (Edvardson et al., 2012).

As services are co-produced, their development might require co-design which refers to collective creativity across the whole design process (Durugbo, 2014). In their study, Sanders and Stappers (2008) demonstrate why it is extremely important to service design as the combination is needed to understand the service demand side and the customers' needs side.

\section{Proposed Framework: Putting it Together}

We have summarized our discussion of service design in the framework shown in Table 1. (see next page) 
Table 1: Proposed Framework

\begin{tabular}{|c|c|c|c|}
\hline Activities & Marketing Role & Customer Role & Design Science Concepts \\
\hline Problem surfacing & Coach & Client & $\begin{array}{l}\text { Psychometric measurement and } \\
\text { analysis: interviews, focus groups, } \\
\text { perceptual mapping, CIT; job- } \\
\text { centric approach }\end{array}$ \\
\hline \multirow[t]{2}{*}{ Problem structuring } & Analyst & $\begin{array}{l}\text { Usage subject matter } \\
\text { expert }\end{array}$ & $\begin{array}{l}\text { Invention Axiom (3): definition and } \\
\text { prioritization of problem in terms of } \\
\text { tradeoffs and breakthroughs } \\
\text { required, }\end{array}$ \\
\hline & & & $\begin{array}{l}\text { Conjoint Analysis, Lead user } \\
\text { Analysis }\end{array}$ \\
\hline Solution imagining & $\begin{array}{l}\text { Experimenter: } \\
\text { thought, virtual } \\
\text { and material }\end{array}$ & Sounding board & Invention Axiom (3) \\
\hline \multirow[t]{2}{*}{ Innovation creating } & $\begin{array}{l}\text { Role play } \\
\text { customer }\end{array}$ & Role player & $\begin{array}{l}\text { Information or comprehensiveness } \\
\text { Axiom (2): }\end{array}$ \\
\hline & & & $\begin{array}{l}\text { Independence or standing after } \\
\text { failure Axiom (1): Competitive } \\
\text { Necessity, Information }\end{array}$ \\
\hline $\begin{array}{l}\text { Innovation } \\
\text { optimizing }\end{array}$ & $\begin{array}{l}\text { Customer } \\
\text { Engineering }\end{array}$ & Co-designer/validator & Axiom 2: Customer Necessity \\
\hline $\begin{array}{l}\text { Value proposition } \\
\text { developing }\end{array}$ & Value optimizer & Value validator & $\begin{array}{l}\text { System optimization: } \\
\text { blueprinting/servicescapes, pricing } \\
\text { (metered, bundling, fermium, } \\
\text { subscription) }\end{array}$ \\
\hline Value delivering & $\begin{array}{l}\text { Delivery point } \\
\text { provider }\end{array}$ & $\begin{array}{l}\text { Value co-creator and } \\
\text { benefiter }\end{array}$ & $\begin{array}{l}\text { Feedback to satisfaction } \\
\text { maintenance and problem surfacing }\end{array}$ \\
\hline
\end{tabular}

This framework lays out the respective key roles of marketing and customers for each activity of the design process. The framework also shows the design science concepts that are most salient for each activity. The steps of the design process are 'Problem Surfacing', 'Problem Structuring’, 'Solution Imagining’, 'Innovation Creating', ‘Innovation Optimizing’, ‘Value Proposition Developing', and 'Value Delivering'. The framework relies on the essential features of service science/S-D logic in that it incorporates customers as co-creators or co-producers (Vargo \& Lusch, 2004) and service as a process (Grönroos \& Gummerus, 2014). 
It does maintain an essential distinction that service providers are different from customers and the two exchange values. More often than not in commercial exchanges, we expect that customers obtain a solution in exchange for which they pay with one or more monetary transactions.

In Step 1, the role of the marketer is of a coach who engages with the client to clarify the problem that the client faces and to bring it to the surface from complexities of the context in which it is hidden. The coach has to clarify the problem in terms that the client will feel that if it is solved, the solution will indeed add value. At the problem structuring step the marketer acts as an analyst and uses the knowledge of the customer to structure the problem such that this structure can direct the design of an effective and value maximizing process solution or service solution. At the solution imagining step the marketer acts as an experimenter developing possible solutions. The client is used as a sounding board to test out possible solutions. At the innovation creating step, the roadblocks to a successful solution are examined and the necessary solutions obtained. At the innovation optimizing step the marketer plays the role of a customer engineer and calibrates, readjusts and sets the service process elements and their interconnections to balance the value to both the firm and its customers. At the value proposition developing stage the marketer's role is to frame the value such that it is understandable to customers and position it in compelling terms. At this step customer reactions may be observed to provide feedback to help optimize the value proposition. The last step is that of value delivery. The marketer delivers value (in both value proposition form and value as experienced) to both the customer and to the firm. The service must be designed such that value can be exchanged with minimal loss and maximum gain to the entire system from customer to firm to customer. Figure 3 graphically depicts the proposed framework. 


\section{Figure 3: A Graphical Representation of the Proposed Framework}

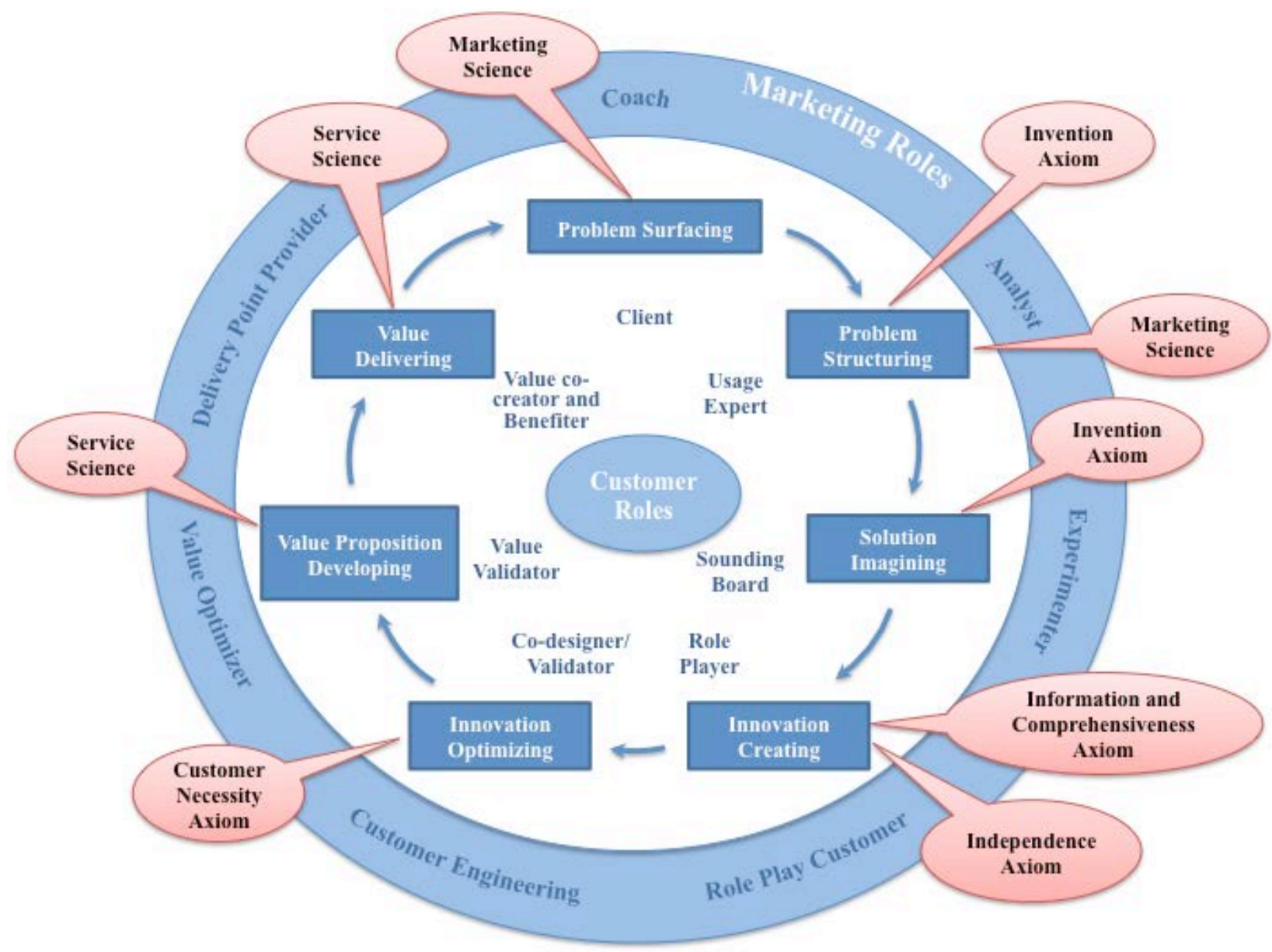

To follow the steps of the proposed framework in Figure 3, consider the following example of a restaurant wishing to create an innovation. Using standard marketing research techniques assume that it has been discovered that patrons are not fully satisfied by the meal though they are satisfied by the individual menu items (problem surfacing stage). Further observations revealed of their interactions, their verbalizations during consuming their meal, and by asking pointed questions at various phases of their visit including at various points during their meal, service employees, acting as “coaches,” discovered that most of patrons' hesitation, as clients, occurred during wine selection. View backs of video recordings (of course with patron permission) and analysis using new video analysis technique and the expertise of the coaches revealed that most 
of the hesitation in decision making and awkwardness in group interactions were over the selection of wines to go with individual meals.

Further analysis revealed that the problem could be structured as (a) uncertainty as to the appropriate wine-meal pairings, (b) discussion of such pairings between patrons, (c) choice of a single wine to go with the meals chosen by different individuals in a group, (d) discomfort in revealing knowledge or lack of it regarding wines, and (e) budget concerns (problem structuring stage). All these individual issues seem to present themselves as less than a very high level of satisfaction and cognitive dissonance. If not corrected it could lead to diminished probability of repeat patronage. The problem was thus structured to cover individual knowledge, group interactions, and budget concerns. On the restaurant side the objectives were to improve customer satisfaction and loyalty.

At this stage some experimentation was carried out to aid in arriving at imaginative solutions to the problem (unearthed as the uncertainty related to the food-wine pairings, cognitive dissonance with their choices, reluctance to exhibit ignorance or lack of experience with wine selection, diversity of meal orders by patrons at a table/group, and the need to both show a group consonance by ordering a common bottle as well as to not inflate their wine costs). Even when there is a sommelier to make recommendations or a so-called wine expert in the group, individuals still exhibits concerns about their choice and therefore less than complete satisfaction (invention axiom). It was also observed that some groups have a single wine expert while some does not, some have multiple experts (providing an opportunity for conflict, some drink a lot and some do not, etc.).

Some solutions imagined/considered were to (1) provide wine pairings with each food item on the menu and (2) to train sommeliers to identify wine experts and non-experts and interact with them differently (solution imagining stage). However, neither alternative resolved the 
tradeoff between satisfying matching each individual's order to the matching wine (raising the wine bill because of multiple and different wine-by-glass orders) and lowering the wine bill; between validating the knowledge of wine experts and minimizing the negative feelings of novices; between providing recommendations and matching individual taste preferences (invention axiom). During this imagining process, patrons need to act as sounding boards to help in the co-creation of the innovation.

A breakthrough solution was the provision of a sampler wine glasses, providing multiple small glasses along with a course per person, followed with taking an order for the type that best suited an individual palette; providing a website with wine matchings for patrons to read before coming to the restaurant, and providing an augmented reality menu that provided information on provenance, expected taste, expert recommended matchings, as well as experiences of past patrons (innovation creating stage). During this stage, patrons need to play their role and react to the propositions made by the staff. To complete the design, the restaurant had to make sure that they could make changes to menu, wine selection, and sommelier recommendations such that an error/change in one did not cause cascading problems or significant increase in costs (independence axiom). The design had to be such that there will be a minimal time gap between a patron choosing between samples of wines and choosing a full glass/bottle (information axiom).

The next step (innovation optimizing stage) was to create alternative combinations of the design features (as derived earlier) and set up trials to obtain customer reactions, as co-designers and validators, and measurements using say conjoint analysis or other preference optimization techniques, such as sensory optimization (customer necessity axiom). Having validated at a possibly optimal customer solution, the next step was to develop the entire process using a tool such as service blueprinting (value proposition developing stage). This required careful thought to monitor and optimize layout, exact sizes, timing, and probes to interact with patrons, as value 
validators, both virtually and by wait staff/sommeliers (service science). The next step was to develop a positioning statement that conveys the differential advantage and the customer benefit in a manner that fit the patron segments that the restaurant wished to serve (value delivering stage). Notice how the imaginative solution has closely embedded customer co-creation not only in the consumption stage but also in many stages of the design process in order to create value for both customers and the restaurant.

\section{Conclusion and Future Research}

The incremental contributions of our paper as summarized by the framework in Table 1 are: (1) it specifies the particular co-production role of customers at each step, and (2) it introduces three design science axioms as providing a rock solid foundation to guide service design.

While at first glance one may be dismissive of the design science axioms as being holdovers from a goods dominant view of the world, we suggest that they bear a closer look. These axioms are rooted in information theory and thus their ambit is naturally very broad. The reason for our proposition that they are useful is the basic fact that service, from the S-D logic perspective, is at its core viewed as being a process. Thus this process has stages and each stage communicates with the other(s). Further, these stages have to be designed and should be such that together they deliver value to customers. The service process may develop errors that need to be rectified. To ensure that customers get value even if a part of the process works incompletely, to be able to diagnose and rectify errors quickly, and to be able to accommodate heterogeneity in the specificity of customer needs, variances across employees and contexts of delivery, Axioms 1 and 2 must be met.

Future work must develop specific valid and reliable instruments for establishing the axioms from a customer viewpoint. It must also consider how the axioms may be used in the context of 
incremental design improvements. Such improvements will impose constraints on what can be changed. However the science behind design implies that such changes themselves should be subject to the axioms. We believe these issues if addressed will add not only to service design but will also, in turn, lead to better solutions and experiences for customers. Moreover, future work might also seek to assess the validity and the reliability of the framework by applying it across a wide range of contexts. This would enhance the rigor and relevance of the proposed framework (Hevner et al., 2004).

In conclusion this paper provides an overview of the literatures in marketing science, services design, and the innovation design science. It then provides a brief description of a framework to integrate the developments in these separate literatures. While the current thinking is that services are designed and then delivered as co-creation or co-production processes, it is possible with new technologies for automated and/or contemporaneous service design to occur. For example Zomerdijk and Voss (2012), through their case studies, show that service organizations are managing customer experiences even closer than usual. To develop contemporaneous design and delivery processes will call for the development of new and specific methodologies for which the axioms identified in this paper can provide a valuable scientific foundation. 


\section{Notes}

1 There is a strong stream of research (notably Hevner et al., 2004, Hevner \& Chatterjee, 2010) on design science research in information systems. Their work provides invaluable directions for design science research even though it is specially oriented to the various elements and linkages of information systems. Hevner et al. (2004) provide seven guidelines for conducting research on service design. The seven guidelines are: (1) Design as an artifact, (2) problem relevance, (3) design evaluation, (4) research contributions, (5) research rigor, (6) design as a search process, and (7) communications of research. For our purposes in developing a framework for designing new services in contrast to providing a framework for conducting design science research we sought out and have brought to the current audience axioms from the literature that focus on understanding and determining when a design is an innovation and when it is a good innovation that is both an invention and commercially valuable. The Design Science literature that we have cited provides the framework that we believe meets our goals. 


\section{References}

Altshuller, G. S. (1986). To Find an Idea: Introduction to the Theory of Solving Problems of Inventions, Novosibirsk, Nauka, USSR.

Altshuller, G. S. (1988). Creativity as an Exact Science, Gordon and Breach, New York.

Altshuller, G. S. (1996). And Suddenly the Inventor Appeared: TRIZ: The Theory of Inventive problem Solving, Technical Innovation Center, Worcester, MA.

Bitner, M. J. (1992). Servicescapes: The impact of physical surroundings on customers and employees. Journal of Marketing, 5, 57-72.

Buchenau, M., \& Suri, J. F. (2000). Experience Prototyping. Symposium on Designing Interactive Systems, 424-433.

Burgers, A., de Ruyter, K., Keen, C., \& Streukens, S. (2000). Customer expectation dimensions of voice-to-voice service encounters: A scale-development study. International Journal of Service Industry Management, 11, 142-161.

Camm, J. D., Cochran, J. J., Curry, D. J., \& Kannan, S. (2006) Conjoint optimization: An exact branch-and-bound algorithm for the share-of-choice problem. Management Science, 52, 435-447.

Carlborg, P., Kindström, D., \& Kowalkowski, C. (2014). The evolution of service innovation research: A critical review and synthesis. The Service Industries Journal, 34, 373-398.

Chai, K. H., Zhang, J., \& Tan, K. C. (2005). A TRIZ-based method for new service design. Journal of Service Research, 8(1), 48-66.

Dourson, S. (2004). The 40 inventive principles of TRIZ applied to finance. The TRIZ journal, January, 1-23.

Droege, H., Hildebrand, D., \& Heras Forcada, M. A. (2009). Innovation in services: Present findings, and future pathways. Journal of Service Management, 20, 131-155.

Dubé, L., Johnson, M. D., \& Renaghan, L. M. (1999). Adapting the QFD approach to extended service transactions. Production and Operations Management, 8, 301-317.

Durugbo, C. (2014). Managing industrial service co-design: identifying challenges from technology firms. The Service Industries Journal, 34, 314-334.

Edvardsson, B., Kristensson, P., Magnusson, P., \& Sundström, E. (2012). Customer integration within service development-A review of methods and an analysis of insitu and exsitu contributions. Technovation, 32, 419-429.

Edvardsson, B., Tronvoll, B., \& Gruber, T. (2011). Expanding understanding of service exchange and value co-creation: a social construction approach. Journal of the Academy of Marketing Science, 39, 327-339.

Eiglier, P. and Langeard, E. (1976). Principe de politique marketing pour les enterprises de service [Principle of marketing management for services firms]. working paper, Institute d'Administration des Enterprises, Université d'Aix-Marseille.

Fisk, R. P., Brown, S. W., \& Bitner, M. J. (1993). Tracking the evolution of the services marketing literature. Journal of Retailing, 69, 61-103.

Frei, F. (2006). Breaking the trade-off between efficiency and service. Harvard Business Review, 84, 92-101. 
Gadrey, J. and Gallouj, F. (2002), Productivity, Innovation and Knowledge in Services: New Economic and Socio-Economic Approaches, Edward Elgar, Cheltenham, UK.

Gonçalves-Coelho, A. M., \& Mourao, A. J. (2007). Axiomatic design as support for decisionmaking in a design for manufacturing context: A case study. International Journal of Production Economics, 109, 81-89.

Green, P. E., \& Srinivasan, V. (1978). Conjoint analysis in consumer research: Issues and outlook. Journal of Consumer Research, 5, 103-123.

Green, P. E., Carroll, J., \& Goldberg, S. (1981). A general approach to product design optimization via conjoint analysis. Journal of Marketing, 45, 17-35.

Green, P. E., \& Srinivasan V. (1990). Conjoint analysis in marketing: New developments with implications for research and practice. Journal of Marketing, 54, 3-19.

Griffin, A., \& Hauser, J.R. (1993). The voice of the customer. Marketing Science, 12, 1-27.

Grönroos, C., \& Gummerus, J. (2014). The service revolution and its marketing implications: service logic vs. service-dominant logic. Managing Service Quality, 24, 206-229.

Gruca, T. S., Sudharshan, D., \& Kumar, K. R. (1995). Nicher: An approach to identifying defensible product positions. European Journal of Operational Research, 84, 292-309.

Hauser, J. R., \& Clausing, D. (1988). The house of quality. Harvard Business Review, 66, 63-73.

Hauser, J., Tellis, G. J., \& Griffin, A. (2006). Research on innovation: A review and agenda for marketing science. Marketing Science, 25, 687-717.

Herstatt, C., \& von Hippel, E. (1992). From experience: Developing new product concepts via the lead user method: A case study in a "low-tech" field. Journal of Product Innovation Management, 9, 213-221.

Hevner, A., \& Chatterjee, S. (2010). Design Research in Information Systems: Theory and Practice (Vol. 22). Springer Science \& Business Media.

Hevner, A. R., March, S. T., Park, J., \& Ram, S. (2004). Design science in information systems research. MIS Quarterly, 28, 75-105.

Hilton, T., \& Hughes, T. (2008). Co-production and co-creation using self service technology: The application of service-dominant logic. The Otago Forum 2, 8-12 December, Dunedin, New Zealand.

IBM (s.d.). The origins of computer science. available at: http://www03.ibm.com/ibm/history/ibm100/us/en/icons/compsci/ (accessed March 11 ${ }^{\text {th }}$, 2016).

Katz, G. M. (2001). The “one right way” to gather the voice of the customer. PDMA Visions, 25, $1-6$.

Kelly, D., \& Storey, C. (2000). New service development: Initiation strategies. International Journal of Service Industry Management, 11, 45-63.

Kim, S., \& Yoon, B. (2012). Developing a process of concept generation for new product-service systems: A QFD and TRIZ-based approach. Service Business, 6, 323-348.

Kimbell, L. (2011), Designing for service as one way of designing services. International Journal of Design, 5, 41-52.

Kotler, P., Keller, K.L., Ancarani, F. and Costabile, M. (2015), Marketing Management 15/e. Pearson. 
Langeard, E. and Eiglier, P. (1987), Servuction: Le Marketing des Services [Servuction: Services Marketing], Wiley, Paris.

Li, J. H., Xu, L., \& Wu, X. L. (2009). New service development using GAP-based QFD: A mobile telecommunication case. International Journal of Services Technology and Management, 12, 146-174.

Lilien, G. L., Morrison, P. D., Searls, K., Sonnack, M., \& von Hippel, E. (2002). Performance assessment of the Lead User idea-generation process for new product development. Management Science, 48, 1042-1059.

Lin, C. J., \& Cheng, L. Y. (2015). An integrated model of service experience design improvement. The Service Industries Journal, 35, 62-80.

Lüthje, C., \& Herstatt, C. (2004). The Lead User method: an outline of empirical findings and issues for future research. $R \& D$ Management, 34, 553-568.

Lusch, R. F., \& Vargo, S. L. (2008). Why “service”? Academy of Marketing Science Journal, 36, 25-38.

Lusch, R. F., Vargo, S. L., \& Wessels, G. (2008). Toward a conceptual foundation for service science: Contributions from service-dominant logic. IBM Systems Journal, 47, 5-14.

Maglio, P. P., \& Spohrer, J. (2008). Fundamentals of service science. Journal of the Academy of Marketing Science, 36, 18-20.

McColl-Kennedy, J. R., Cheung, L., \& Ferrier, E. (2015) Co-creating service experience practices. Journal of Service Management, 26, 249-275.

Maimon, O.Z., \& Horowitz, R. (1999). Sufficient conditions for inventive solutions. IEEE Transactions on Systems, Man, and Cybernetics-Part C: Applications and Reviews, 29, 349-361.

Mann, D. (1999a). Axiomatic Design And TRIZ: Compatibilities and Contradictions. The TRIZ Journal, June, Article 1, available at: http://www.triz-journal.com/archives/1999/06/ (accessed 11 March 2016)

Mann, D. (1999b). Axiomatic design and TRIZ: Compatibilities and contradictions Part II. The TRIZ Journal, July, Article 6, available at: http://www.triz-journal.com/archives/1999/07/ (accessed 11 March 2016).

Menor, L. J., Tatikonda, M. V., \& Sampson, S. E. (2002). New service development: areas for exploitation and exploration. Journal of Operations Management, 20, 135-157.

McQuarrie, E. F. (1998). Customer Visits, Sage Publications, Thousand Oaks, CA.

Moore, G. E. (1965). Cramming more components onto integrated circuits. Electronics, 38, 114117.

Nijssen, E. J., Hillebrand, B., Vermeulen, P. A., \& Kemp, R. G. (2006). Exploring product and service innovation similarities and differences. International Journal of Research in Marketing, 23, 241-251.

Ostrom, A. L., Bitner, M. J., Brown, S. B., Burkhard, K. A., Goul, M., Smith-Daniels, V., Demirkan, H., \& Rabinovich, E. (2010). Moving forward and making a difference: Research priorities for the science of service. Journal of Service Research, 13, 4-36.

Parasuraman, A., Berry, L. L., \& Zeithaml, V. A. (1991). Refinement and reassessment of the SERVQUAL scale. Journal of Retailing, 67, 420-450. 
Parasuraman, A., \& Grewal, D. (2000). The impact of technology on the quality-value-loyalty chain: A research agenda. Journal of the Academy of Marketing Science, 28, 168-174.

Parasuraman, A, Zeithaml, V. A., \& Berry, L. L. (1988). SERVQUAL: A Multi-item Scale Measuring Consumer Perceptions of Service Quality. Journal of Retailing, 64, 12-37.

Patrício, L., \& Fisk, R. P. (2013). Creating new services. In Serving Customers Globally, ed. Russell-Bennett R., Fisk, R.P. and Harris, L., Tilde University Press.

Ryu, H. S., \& Lee, J. N. (2016). Innovation patterns and their effects on firm performance. The Service Industries Journal, 36, 81-101.

Sanders, E. B. N., \& Stappers, P. J. (2008). Co-creation and the new landscapes of design. CoDesign, 4, 5-18.

Schreier, M., \& Prügl, R. (2008). Extending Lead-User theory: Antecedents and consequences of consumers’ Lead Userness. Journal of Product Innovation Management, 25, 331-346.

Sheth, J.N., Newman, B.I. and Gross, B.L. (1991b), Consumption Values and Market Choices: Theory and Applications, South-Western Publishing, Cincinnati.

Shostack, L. G. (1977). Breaking free from product marketing. Journal of Marketing, 41, 73-80.

Shostack, L. G. (1984). Designing services that deliver. Harvard Business Review, 62, 133-139.

Shostack, L. G. (2001). How to design a service. European Journal of Marketing, 16, 49-63.

Simon, H. A. (1956). The Sciences of the Artificial, MIT Press, Cambridge, MA.

Slocum, M. S. (2014). Axiomatic innovation: Creativity as an exact science. The Triz Journal, available at: http://www.triz-journal.com/innovation-methods/innovation-triz-theoryinventive-problem-solving/axiomatic-innovation-creativity-exact-science/ (accessed September 2015).

Spohrer, J., \& Maglio, P. P. (2008). The emergence of service science: Toward systematic service innovations to accelerate co-creation of value. Production and Operations Management, 17, 238-246.

Steen, M., Manschot, M., \& De Koning, K. (2011). Benefits of co-design in service design projects. International Journal of Design, 5, 53-60.

Sudharshan, D., May, J. H., \& Shocker, A. D. (1987). A simulation comparison of methods for new product location. Marketing Science, 6, 182-201.

Sudharshan, D., May, J. H., \& Gruca, T. S. (1988). DIFFSTRAT: An analytical procedure for generating optimal new product concepts for a differentiated-type strategy. European Journal of Operational Research, 31, 50-65.

Sudharshan, D., \& May, J. H. (1992). GLOBESTRAT: Designing product lines for global markets. Journal of Mathematical Computer Modeling, 16, 27-35.

Suh, N. P. (1990). The Principles of Design, Oxford University Press, New York.

Suh, N. P. (2001). Axiomatic Design: Advances and Applications, Oxford University Press, New York.

Suh, N. P. (2005). Complexity: Theory and Applications, Oxford University Press, New York.

Sushkov, V. V., Mars, N. J., \& Wognum, P. M. (1995). Introduction to TIPS: A theory for creative design. Artificial Intelligence in Engineering, 9, 177-189. 
Szende, P., \& Dalton, A. (2015). Service blueprinting: Shifting from a storyboard to a scorecard. Journal of Foodservice Business Research, 18, 207-225.

Tan, K. C., \& Pawitra, T. A. (2001). Integrating SERVQUAL and Kano's model into QFD for service excellence development. Managing Service Quality: An International Journal, 11, 418-430.

Tari Kasnakoglu, B. (2016). Antecedents and consequences of co-creation in credence-based service contexts. The Service Industries Journal, 36, 1-20.

Teehan, R., \& Tucker, W. (2010). A simplified lean method to capture customer voice. International Journal of Quality and Service Sciences, 2, 175-188.

Thomke, S. H. (2003), Experimentation Matters: Unlocking the Potential of New Technologies for Innovation, Harvard Business Press, Boston, MA.

Toubia, O., Simester, D. I., Hauser, J. R., \& Dahan, E. (2003). Fast polyhedral adaptive conjoint estimation. Marketing Science, 22, 273-303.

Urban, G. L., \& Hauser, J. R. (2004). Listening in' to find and explore new combinations of customer needs. Journal of Marketing, 68, 72-87.

Urban, G. L., Weinberg, B. D., \& Hauser, J. R. (1996). Premarket forecasting of really-new products. Journal of Marketing, 60, 47-60.

Urban, G. L., \& von Hippel, E. (1988). Lead User analyses for the development of new industrial products. Management Science, 34, 569-582.

Vaishnavi, V. K., \& Kuechler, W. (2015). Design Science Research Methods and Patterns: Innovating Information and Communication Technology, CRC Press.

Vargo, S. (2009). Toward a transcending conceptualization of relationship: a service dominant logic perspective. Journal of Business \& Industrial Marketing, 24, 373-379.

Vargo, S. L., \& Akaka, M. A. (2009). Service-dominant logic as a foundation for service science: clarifications. Service Science, 1, 32-41.

Vargo, S. L., \& Lusch, R. F. (2011). Service-Dominant Logic: Premises, Perspectives, Possibilities, Cambridge University Press. Cambridge.

Vargo, S. L., \& Lusch, R. F. (2004). Evolving to a new dominant logic for marketing. Journal of Marketing, 68, 1-17.

Vargo, S. L., Maglio, P. P., \& Akaka, M. A. (2008). On value and value co-creation: A service systems and service logic perspective. European Management Journal, 26, 145-152

Von Hippel, E. (1976). The dominant role of users in the scientific instrument innovation process. Research Policy, 5, 212-239.

Von Hippel, E. (1977). The dominant role of the user in semiconductor and electronic subassembly process innovation. IEEE Transactions on Engineering Management, 24, 6071.

Von Hippel, E. (1986). Lead Users: A source of novel product concepts. Management Science, 32, 791-805.

Wikipedia, “TRIZ”, available at: http://en.wikipedia.org/wiki/Algorithm_of_inventive_problems_solving (accessed 11 March 2016). 
Zhang, J., Chai, K. H., \& Tan, K. C. (2003). 40 inventive principles with applications in service operations management. The TRIZ Journal, December, 1-16.

Zomerdijk, L. G., \& Voss, C. A. (2012). Service design for experience-centric services. Journal of Service Research, 15, 127-159. 


\begin{abstract}
Authors
Olivier FURRER

Department of Business Administration, University of Fribourg, Bd de Pérolles 90, 1700 Fribourg, Switzerland, phone: +41 26300 8306, email: olivier.furrer@unifr.ch
\end{abstract}

Devanathan SUDHARSHAN

Gatton College of Business and Economics, University of Kentucky, 255 Gatton College Building, Lexington KY 40506, USA phone: +1 859257 8939, email: devanathan.sudharshan@uky.edu

Rodoula H. TSIOTSOU

Department of Business Administration, University of Macedonia, 156 Egnatia Str., Thessaloniki 54636, Greece phone: +3 23108 9157, email: rtsiotsou@gmail.com

Ben S. LIU

Department of Marketing, Lender School of Business Center, Quinnipiac University, 275 Mt. Carmel Avenue, Hamden, CT 06518, USA, phone: +1 203582 3772, email: ben.liu@quinnipiac.ed

\begin{abstract}
Drawing on research from design science, marketing and service science, our paper provides an integrated framework for evaluating and directing innovative service design. The main goal of our review is to highlight the strengths of existing frameworks and to suggest how they can be enhanced in combination with design science principles. Based on our review, we propose a new framework for the design of innovative services that integrates several key paradigmatic approaches and identifies fundamental open research questions. Our approach is unique as it combines three service disciplines, namely services marketing, service science, and design science, and provides a new framework that describes step by step the procedure that needs to be taken and the conditions that need to be met for developing innovative services. We believe that providing such a framework is a valuable addition to the literature.
\end{abstract}

\title{
Citation proposal
}

Olivier Furrer, Devanathan Sudharshan, Rodoula H. Tsiotsou, Ben S. Liu. 2016. «A Framework for Innovative Service Design». Working Papers SES 476, Faculty of Economics and Social Sciences, University of Fribourg (Switzerland)

\section{Jel Classification}

\author{
M31, 032
}

\section{Keywords}

Service design, Services innovation, Marketing science, Design science, Service-dominant logic, Customer co-creation, Customer co-production

\section{Working Papers SES collection}

\section{Last published}

471 Mueller G. P.: On the Use of Interview Data for the Microsimulation of Ideological Conflicts: An Analysis of the Political Cleavages of the European Left; 2016

472 Huber M., Tyahlo S.: How war affects political attitudes: Evidence from eastern Ukraine; 2016

473 Deuchert E., Huber M., Schelker M.: Direct and indirect effects based on difference-in-differences with an application to political preferences following the Vietnam draft lottery; 2016

474 Grossmann V., Schäfer A., Steger T., Fuchs B.: Reversal of Migration Flows: A Fresh Look at the German Reunification; 2016

475 Pesenti A.: The Meaning of Monetary Stability; 2016

\section{Catalogue and download links}

http://www.unifr.ch/ses/wp

http://doc.rero.ch/collection/WORKING_PAPERS_SES

\section{Publisher}

Université de Fribourg, Suisse, Faculté des sciences économiques et sociales Universität Freiburg, Schweiz, Wirtschafts- und sozialwissenschaftliche Fakultät University of Fribourg, Switzerland, Faculty of Economics and Social Sciences
Bd de Pérolles 90, $\mathrm{CH}-1700$ Fribourg

Tél.: +41 (0) 263008200

decanat-ses@unifr.ch www.unifr.ch/ses 